in vivo $34: 2751-2756(2020)$

doi:10.21873/invivo.12098

\title{
Rare Case of Renal-type Clear Cell Carcinoma of the Prostate and Review of the Literature
}

\author{
SONG IY HAN ${ }^{1}$ and SUNG-CHUL LIM ${ }^{2}$ \\ ${ }^{1}$ Division of Premedical Science, College of Medicine, Chosun University, Gwangju, Republic of Korea; \\ ${ }^{2}$ Department of Pathology, College of Medicine, Chosun University, Gwangju, Republic of Korea
}

\begin{abstract}
Background/Aim: Renal-type clear cell carcinoma (RTCCC) occurring as a primary tumor in an extra-renal location, especially in the prostate, is very rare. In this report, we present a rare case of RTCCC of the prostate and review the current literature on this condition. Case Report: The patient was a 76-year-old man who presented with urinary symptoms. Cystoscopic findings showed tumor-like lesions in the dome, neck, and anterior wall of the urinary bladder. Biopsy revealed clear cell carcinoma (CCC). Transrectal needle biopsy of the prostate revealed prostatic adenocarcinoma with CCC features. Immunohistochemically, tumor cells of the bladder and prostate were compatible with prostatic carcinoma. The whole-body radiologic workup did not reveal any renal or other organ malignancies. Transurethral resection of the prostate and bladder tumor was performed. The patient underwent regular follow-up cystoscopic examination and urine cytology. No recurrence was observed 19 months after the diagnosis. Conclusion: This was a case of RTCCC arising in the prostate. RTCCC of the prostate is extremely rare and shows very similar histological and immunohistochemical features to those of CCC occurring in the kidney. Pathologists should be aware of such an entity whenever they see clear cells in urinary tract malignancies.
\end{abstract}

Clear cell lesions occurring in the lower urinary tract are rare and often pose diagnostic challenges. Malignant clear cell lesions in the prostate are usually clear cell variants of prostatic adenocarcinoma and transitional cell carcinoma.

This article is freely accessible online.

Correspondence to: Sung-Chul Lim, MD, Ph.D. Department of Pathology Chosun University Hospital, 365, Pilmoon-daero, Donggu, Gwangju, Republic of Korea. Tel: +82 622306343, Fax: +82 622265860,e-mail: sclim@chosun.ac.kr

Key Words: Renal-type, clear cell, carcinoma, prostate, immunohistochemistry.
Clear cell carcinoma (CCC) of the Mullerian type, metastatic renal cell carcinoma (RCC), and renal-type clear cell carcinoma (RTCCC), which was reported for the first time in 2003, occur rarely $(1,2)$. RCC is the most common CCC and usually metastasizes to the lungs, bones, and liver $(3,4)$, but very rarely to the prostate and bladder $(5,6)$. Therefore, RTCCC of the prostate needs to be distinguished from metastatic RCC. However, their histological and immunohistochemical findings are similar to each other; thus, this case report and literature review investigated the features that can assist with differential diagnosis.

\section{Case Report}

A 76-year-old man presented at the Urology outpatient department (OPD) with urinary symptoms. Rectal examination revealed grade II enlargement of the prostate, firm on palpation. Urine examination showed hematopyuria (RBC: many/high power fields [HPF], WBC: 10-19/HPF). His serum prostate-specific antigen (PSA) level was within normal limits $(2.7 \mathrm{ng} / \mathrm{ml})$. Cystoscopic findings showed sessile tumor-like lesions in the neck and anterior wall of the urinary bladder and prostatic urethra. MRI showed illdemarcated T2- low signal intensity areas in the posterior aspect of the right peripheral zone and left peripheral and transitional zone at the basal to apical prostate with extracapsular extension, suggesting prostatic cancer with invasion of the bladder.

Cystoscopic biopsy (first biopsy) showed adenocarcinoma with clear cell features, which showed positive immunoreactivity for $\alpha$-methyl acyl-CoA racemase (AMACR), CD10, and PSA and negative immunoreactivity for cytokeratin (CK) 7 (Figure 1). Thereafter, transurethral resection of the bladder tumor (TUR-BT) (second biopsy) was performed. TUR-BT specimen revealed suburothelial confluent clear cell carcinoma (CCC). Immunohistochemically, tumor cells of the bladder were positive for low-molecular-weight cytokeratin (LMWCK), vimentin, epithelial membrane antigen (EMA), AMACR, PSA, and CD10 and negative for high- molecularweight cytokeratin (HMWCK) and CK7 (Figure 2). 

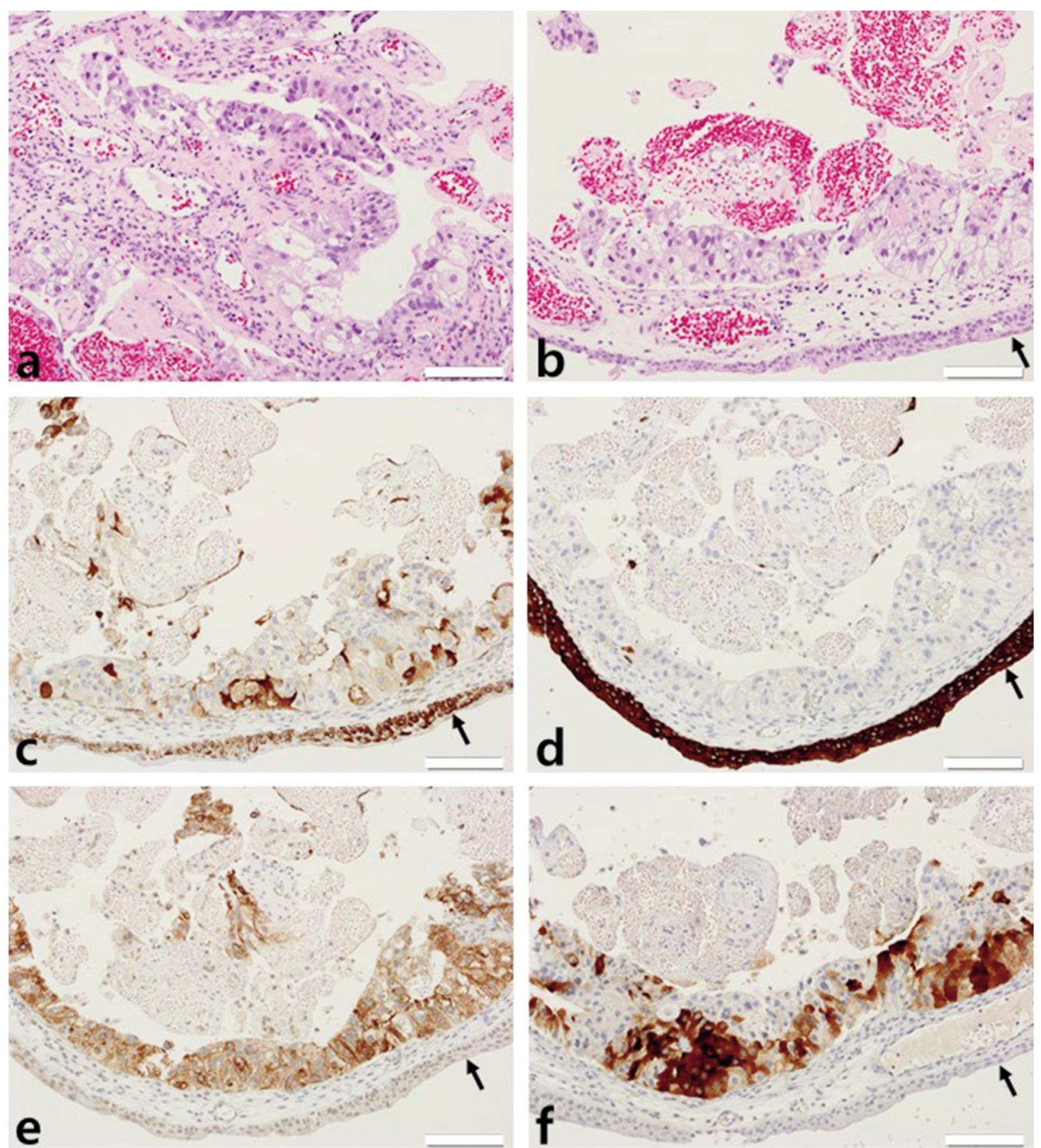

Figure 1. Cystoscopic biopsy showing adenocarcinoma with clear cell features $(a, b)$, which had positive immunoreactivities for CD10 (c), AMACR $(e)$, and PSA (f), but negative for CK7 (d). See the intact overlying urothelial lining (arrows). Scale bar measures 100 $\mu m$.

The whole-body radiologic workup did not reveal any renal or other organ malignancies. The pathology report showed that the results were partially similar to the those of RCC, but there was a high possibility of a prostatic origin. Hence, the patient underwent transrectal needle biopsy of the prostate (third biopsy), which revealed prostatic adenocarcinoma with CCC features and a Gleason score $7(4+3)$ in the core No. 1, 3, 5, and 10. The histomorphological and immunohistochemical findings of the transrectal needle biopsy sample were identical to those 
Table I. Summary of renal-type clear cell carcinoma of the prostate in the literature.

\begin{tabular}{|c|c|c|c|c|c|c|c|c|c|}
\hline No & $\begin{array}{c}\text { Author } \\
\text { (Year) (Ref) }\end{array}$ & $\begin{array}{l}\text { Age } \\
\text { (years) }\end{array}$ & Symptoms & $\begin{array}{l}\text { Serum PSA } \\
\text { at diagnosis }\end{array}$ & Specimen & $\begin{array}{l}\text { Gleason's } \\
\text { score }\end{array}$ & Immunohistochemistry & $\begin{array}{l}\text { Follow-up } \\
\text { (months) }\end{array}$ & Remarks \\
\hline 1 & $\begin{array}{l}\text { Singh et al. } \\
\text { (2003) (2) }\end{array}$ & 73 & $\begin{array}{l}\text { Urinary } \\
\text { symptoms }\end{array}$ & $1.5 \mathrm{mg} / \mathrm{dl}$ & $\begin{array}{l}\text { TUR-P followed } \\
\text { by radical CP } \\
\text { \& pelvic LND }\end{array}$ & $3+3$ & $\begin{array}{c}\text { Positive: Vimentin, EMA, } \\
\text { LMWCK, CD10 Negative: PSA, } \\
\text { PSAP, S-100, HMB-45, Pan-CK, } \\
\text { CK7, CK20, HMWCK, CA-125, } \\
\text { CEA, ER, PR }\end{array}$ & NED (7) & \\
\hline 2 & $\begin{array}{l}\text { Pal \& } \\
\text { Chowdhury } \\
\text { (2007) (8) }\end{array}$ & 64 & NA & $2.1 \mathrm{ng} / 1$ & TUR-P & $3+3$ & $\begin{array}{c}\text { Positive: Pan-CK, Vimentin, } \\
\text { EMA Negative: PSA, PSAP, } \\
\text { HMWCK }\end{array}$ & NED (12) & \\
\hline 3 & $\begin{array}{l}\text { Permi et al. } \\
\text { (2011) (9) }\end{array}$ & 64 & $\begin{array}{l}\text { Urinary } \\
\text { symptoms }\end{array}$ & $82 \mathrm{ng} / \mathrm{ml}$ & $\begin{array}{l}\text { TUR-P followed } \\
\text { by radical CP } \\
\text { \& pelvic LND }\end{array}$ & $3+3$ & $\begin{array}{l}\text { Positive: Vimentin, LMWCK, } \\
\text { EMA Negative: HMWCK, PSA }\end{array}$ & NED (12) & \\
\hline 4 & $\begin{array}{l}\text { Wang \& Xue } \\
\text { (2015) (7) }\end{array}$ & 64 & $\begin{array}{l}\text { Urinary } \\
\text { symptoms }\end{array}$ & $10.2 \mathrm{ng} / \mathrm{ml}$ & TUR-P & $4+4$ & $\begin{array}{l}\text { Positive: Vimentin, EMA, } \\
\text { AMACR, LMWCK, PSAP } \\
\text { Negative: PSA, Pan-CK, } \\
\text { HMWCK, PAX8, CEA }\end{array}$ & DOD (6) & $\begin{array}{l}\text { Lungs, } \\
\text { bones } \\
\text { metastasis } \\
\text { at diagnosis }\end{array}$ \\
\hline 5 & $\begin{array}{l}\text { Patne } \text { et al. } \\
(2015)(10)\end{array}$ & 72 & $\begin{array}{l}\text { Urinary } \\
\text { symptoms }\end{array}$ & $65.2 \mathrm{ng} / \mathrm{ml}$ & $\begin{array}{c}\text { Radical } \\
\text { prostatectomy }\end{array}$ & $4+4$ & $\begin{array}{c}\text { Positive: Pan-CK, Vimentin, EMA, } \\
\text { CD10, AMACR Negative: } \\
\text { HMWCK, CK7, PSA, PAX8 }\end{array}$ & NED (20) & $\begin{array}{c}\text { Hormone } \\
\text { therapy }\end{array}$ \\
\hline 6 & $\begin{array}{l}\text { Sato et al. } \\
\text { (2016) (11) }\end{array}$ & 54 & $\begin{array}{c}\text { Gross } \\
\text { hematuria }\end{array}$ & $0.19 \mathrm{ng} / \mathrm{ml}$ & $\begin{array}{c}\text { Radical CP } \\
\& \text { pelvic LND }\end{array}$ & NA & $\begin{array}{c}\text { Positive: CK7 } \\
\text { Negative: CK20, PSA }\end{array}$ & DOD (29) & $\begin{array}{c}\text { Recur } \\
\text { (24 months) } \\
\text { TKI therapy }\end{array}$ \\
\hline 7 & $\begin{array}{l}\text { Liao et al. } \\
\text { (2018) (12) }\end{array}$ & 73 & $\begin{array}{l}\text { Urinary } \\
\text { symptoms }\end{array}$ & $33.2 \mathrm{ng} / \mathrm{ml}$ & TUR-BT \& -P & $4+5$ & $\begin{array}{l}\text { Positive: Pan-CK, Vimentin, } \\
\text { EMA, LMWCK, PSA, AMACR, } \\
\text { CD10, PSMA, CK19 Negative: } \\
\text { HMWCK, CK7, CA-125, CK20, } \\
\text { CK34, CD117, PAX8, RCC }\end{array}$ & NA & \\
\hline 8 & $\begin{array}{l}\text { Present } \\
\text { case }(2020)\end{array}$ & 76 & $\begin{array}{l}\text { Urinary } \\
\text { symptoms }\end{array}$ & $2.7 \mathrm{ng} / \mathrm{ml}$ & TUR-BT \& -P & $4+3$ & $\begin{array}{l}\text { Positive: Vimentin, LMWCK, EMA, } \\
\text { AMACR, PSA, CD10 Negative: } \\
\text { HMWCK, CK7, CEA, PAX8 }\end{array}$ & NED (13) & \\
\hline
\end{tabular}

Ref: Reference in the text, PSA: prostate specific antigen, TUR-P: transurethral resection of the prostate, CP: cystoprostectomy, LND: lymph node dissection, EMA: epithelial membrane antigen, LMWCK: low molecular weight cytokeratin, PSAP: prostate specific acid phosphatase, Pan-CK: pancytokeratin, HMWCK: high molecular weight cytokeratin, CEA: carcinoembryonic antigen, ER: estrogen receptor, PR: progesterone receptor, NA: not available, NED: no evidence of disease, PAX8: paired box 8, DOD: die of disease, AMACR: $\alpha$-methylacyl-CoA racemase, PSMA: prostate specific membrane antigen, RCC: renal cell carcinoma, TKI: tyrosine kinase inhibitor.

of the TUR-BT sample. Subsequently, the patient underwent transurethral resection of the prostate (TUR-P). Overall, the TUR-P specimen showed CCC with many similar features to RCC and showed typical prostatic adenocarcinoma (Gleason's score 4+3) in some parts. Immunohistochemically, tumor cells of the prostate were positive for LMWCK, vimentin, EMA, AMACR, PSA, and CD10 and negative for HMWCK, carcinoembryonic antigen (CEA), paired box 8 (PAX8), and CK7 (Figure 3). Based on the clinicopathological findings, it was concluded that this tumor represented RTCCC arising in the prostate. On follow-up 19 months later, at the time of submission of this manuscript, the patient is well with no evidence of disease.

Written informed consent was obtained from the patient for publication of this case report and accompanying images. This study was approved by the institutional review board (Permission number: CHOSUN 2019-02-009-012).

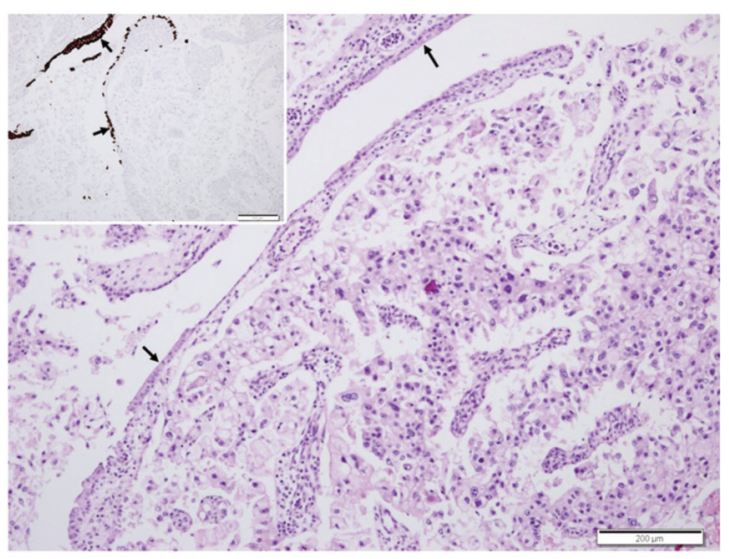

Figure 2. Transurethral resection of the prostate showing renal-type clear cell carcinoma with discontinuous overlying urothelial lining (arrows). Inset: Immunohistochemical staining for CK7. See the CK7 positivity overlying urothelium (arrows), but not in the tumor itself. 

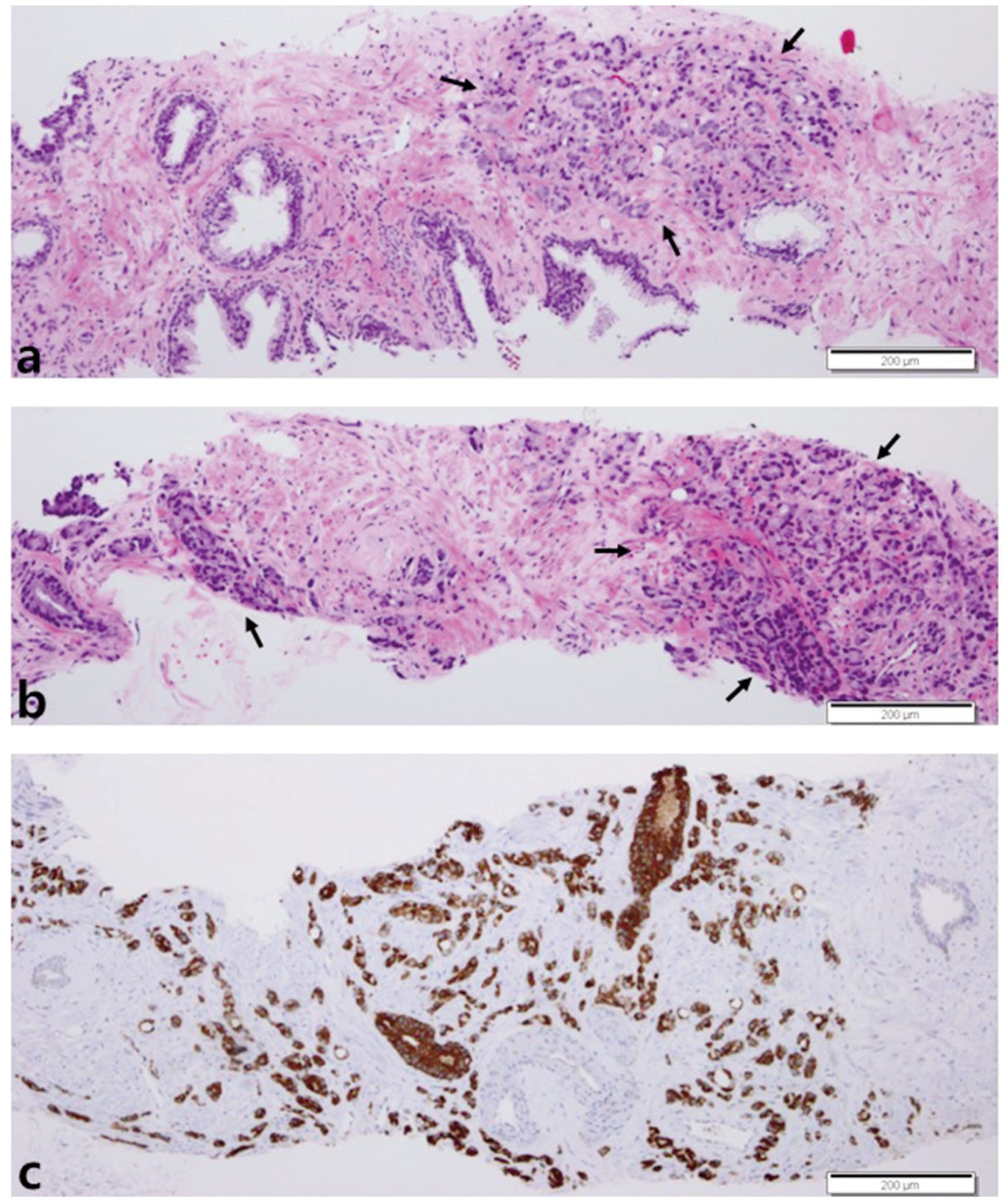

Figure 3. Transurethral resection of the prostate showed prostatic adenocarcinoma (Gleason's score 4+3) (arrows) (a,b) and positive immunoreactivity for prostate-specific antigen (c). 


\section{Discussion}

CCC that occurs in the male lower urinary tract is generally prostatic adenocarcinoma or urothelial carcinoma, but caution is needed because CCC of the Mullerian type and metastatic RCC can rarely occur $(1,2)$. For RCC treated with a different therapy than that for prostatic adenocarcinoma, the clear cell type is the most common, and metastases to the prostate and bladder have been reported $(5,6)$. However, a considerable part of the immunoprofile overlaps with RTCCC of the prostate; thus, differential diagnosis is difficult $(2,7)$. Like RCC, prostatic adenocarcinoma appears as confluent nests of clear cells, but does not have marked vascularity or inflammatory cell infiltration. The typical prostatic adenocarcinoma part somewhat coexists occasionally $(2,7)$. The immunohistochemical staining results showed that RCC had positive Pan-cytokeratin (PanCK), LMWCK, and PSAP and negative HMWCK, vimentin, PSA, CEA, CK7, and CK20. The RTCCCs of the prostate reported thus far generally showed positivity for vimentin, CD10, LMWCK, EMA, MME, and AMACR; partial positivity for PSA, PSAP, AMACR, and Pan-CK; and negativity for HMWCK, CEA, and PAX8 (2, 7-12). RCC is asymptomatic in its early stages and its metastasis to the prostate is extremely rare; thus, metastatic RCC can be differentially diagnosed if renal lesions are not observed on ultrasonographic and computed tomography (CT) scans of the abdomen $(7,10)$. On the other hand, urothelial carcinoma needs to be differentiated if the clear cell pattern is shown and can be differentiated by positive LMWCK, HMWCK, CK7, CK20, and CEA and negative vimentin and PSA. In contrast, the CCC of the Mullerian type can be differentiated by CK7 and CK20 positivity and vimentin and PSA negativity $(2,11)$.

In the case of RTCCC of the prostate, different serum PSA levels are observed, and the immunohistochemical staining results showed that most cases have negative PSA in the clear cell portion $(2,7-11)$, but two cases - including the present case - reported a positive PSA (12). The surrounding accompanied typical prostatic adenocarcinoma area showed positive PSA (10); thus, it would be difficult to predict the origin or subtype of the tumor based on the serum PSA level (Table I). It is presumed that the burden of typical prostatic adenocarcinoma is correlated with the serum PSA level.

RTCCC of the prostate was considered to be the cluster group of RCC based on the microarray cluster analysis. It was determined that $\mathrm{CCC}$ occurred in the embryologic renal remnant in, or adjacent to, the prostate due to the embryogenesis abnormality of the urinary tract system. Tyrosine kinase inhibitor therapy was attempted following the RCC treatment protocol (11). It is anticipated that there will be additional studies on the histogenesis of RTCCC of the prostate.

\section{Conclusion}

Through the present case and literature review, if RTCCC or a similar lesion is observed in the prostate, it should be cautiously diagnosed by combining imaging studies, serum PSA levels, and immunohistochemistry. If there is no proof of a renal origin and serum PSA levels are elevated -or if AMACR or PSA is positive, or PAX8 is negative based on immunohistochemical staining in the CCC area- then RTCCC of the prostate can be considered first.

\section{Conflicts of Interest}

The Authors declare no conflicts of interest.

\section{Author's Contributions}

Data Curation: Song Iy Han. Funding acquisition: Sung-Chul Lim. Methodology: Song Iy Han, Sung-Chul Lim. Supervision: SungChul Lim. Validation: Sung-Chul Lim. Writing - original draft: Song Iy Han. Writing, review and editing: Sung-Chul Lim.

\section{Acknowledgements}

This work was supported by a Research Fund from the Chosun University, 2017.

\section{References}

1 Humphrey PA: Clear cell neoplasms of the urinary tract and male reproductive system. Semin Diagn Pathol 14(4): 240-252, 1997. PMID: 9383824.

2 Singh H, Flores-Sandoval N and Abrams J: Renal-type clear cell carcinoma occurring in the prostate. Am J Surg Pathol 27(3): 407-410, 2003. PMID: 12604899. DOI: 10.1097/00000478200303000-00016

3 Ritchie AW and Chisholm GD: The natural history of renal carcinoma. Semin Oncol 10(4): 390-400, 1983. PMID: 6665566.

4 Flanigan RC, Campbell SC, Clark JI and Picken MM: Metastatic renal cell carcinoma. Curr Treat Options Oncol 4(5): 385-390, 2003. PMID: 12941198. DOI: 10.1007/s11864-0030039-2

5 Cihak RW, Haas R Jr, Koenen CT and Chinchinian H: Metastatic renal carcinoma to the prostate gland: presentation as prostatic hypertrophy. J Urol 123(5): 791792, 1980. PMID: 6158583. DOI: $10.1016 / \mathrm{s} 0022-5347(17) 56135-2$

6 King DH, Centeno AS, Saldivar VA and Sarosdy MF: Renal cell carcinoma metastatic to the gallbladder or prostate: two case reports. Urology 46(5): 722-725, 1995. PMID: 7495130. DOI: 10.1016/S0090-4295(99)80310-0

7 Wang Q and Xue Y: Renal-type clear cell carcinoma of the prostate: A case report. Oncol Lett 9(5): 2149-2152, 2015. PMID: 26137029. DOI: 10.3892/ol.2015.3062

8 Pal DK and Chowdhury MK: Renal type clear cell carcinoma of prostate. Indian J Surg 69(2): 81-84, 2007.

9 Permi HS, Laxminarayana KP, Yeshvanth SK and Shetty JK: Renal type clear cell carcinoma of the prostate: A diagnostic 
dilemma. J Lab Physicians 3(2): 132-133, 2011. PMID: 22219575. DOI: 10.4103/0974-2727.86853

10 Patne SC, Johri N, Katiyar R, Trivedi S and Dwivedi US: Renaltype clear cell carcinoma of the prostate: A diagnostic challenge. Diagn Pathol 10: 193, 2015. PMID: 26498435. DOI: 10.1186/ s13000-015-0432-8

11 Sato Y, Kataoka M, Hata J, Akaihata H, Ogawa S and Kojima Y: Renal-type clear cell carcinoma occurring in the prostate with Zinner syndrome. Urol Case Rep 5: 9-12, 2016. PMID: 26793589. DOI: 10.1016/j.eucr.2015.11.008
12 Liao G, Zhang X, Li Z, Lan S, Huang M and Huang W: Renal type clear cell carcinoma of prostate: A case report and review of literature. Indian J Pathol Microbiol 61(3): 431-3, 2018. PMID: 30004074. DOI: 10.4103/IJPM.IJPM_396_17

Received May 27, 2020

Revised June 12, 2020

Accepted June 12, 2020 